\title{
HAKIKAT PENDIDIK DAN PESERTA DIDIK DALAM SEJARAH ISLAM DAN AL-QURAN
}

\author{
Dini Fauziyati \\ UIN Sunan Kalijaga Yogyakarta \\ dinifauzi233@gmail.com
}

\begin{abstract}
Abstrak
Era digital telah terbuka lebar-lebar. Banyak tantangan-tantangan yang dibadapi di era tersebut. Salah satu tantangan tersebut yaitu tantangan pendidikan, terlebih pada aspek pendidik dan peserta didik. Pendidik dan peserta didik merupakan dua hal bagai sisi mata uang yang tidak. bisa lepas satu sama lain. Diperlukan kajian yang mendalam untuk dapat memahami pendidik dan peserta didik pad hakikatnya. Pendidik dalam Islam, yang lebih dikenal sebagai murobbi berasal dari kata robba, yurobbi, tarbiyatan. Memiliki makna khusus, ada tiga makna yang bisa diambil dari istilah tersebut yaitu; menggali potensi peserta didik, merawat dan melindunginya. Pendidik dalam al-Qur'an ada 4 yaitu; Allab SWT, Nabi Mubammad SAW, Orangtua dan Pendidik dalam artian sebagai pengajar. Metode yang digunakan dalam penelitian ini yaitu library reasearch dengan mencari data dan menganalisis data. Tujuan penelitian ini mencari hakikat pendidik dan peserta didik.
\end{abstract}

\section{Kata Kunci: Hakikat pendidik dan Hakikat Peserta didik.}

\section{A. Pendahuluan}

Pendidikan merupakan usaha sadar dari manusia menuju sebuah proses memanusiakan manusia. Pendidik sebagai pelaku dalam pendidikan sangat menentukan posisi strategisnya dalam mencapai cita-cita bangsa 'mencerdaskan kehidupan bangsa'. Sebagai bangsa yang berketuhanan, perlu mengkaji hakikat pendidik maupun peserta didik dalam Islam.

Pendidik dalam Islam, yang lebih dikenal sebagai murobbi berasal dari kata robba, yurobbi, tarbiyatan. Memiliki makna khusus, ada tiga makna yang bisa diambil dari istilah tersebut yaitu; menggali potensi peserta didik, merawat dan melindunginya. Pendidik dalam al-Qur'an ada 4 yaitu; Allah SWT, Nabi Muhammad SAW, Orangtua dan Pendidik dalam artian sebagai pengajar.

Berbicara pendidik, tentu tidak bisa lepas dari peserta didik sebagai student center. Oleh karena itu dalam makalah ini akan dibahas mengenai hakikat pendidik dan peserta didik dalam Islam serta penulis juga akan menjelaskan peserta didik dan pendidik di dunia Islam pada masa klasik. 


\section{A. Pembahasan}

\section{Hakikat Pendidik}

Menurut Maragustam, hakikat pendidik dalam Islam adalah orang-orang yang bertanggung jawab dalam pengambangan peserta didik dengan mengaktualisasikan seluruh potensinya, baik potensi spiritual, afektif, kognitif maupun potensi psikomotor ke arah yang lebih baik secara seimbang sesuai dengan nilai-nilai Islam. ${ }^{1}$ Al-Qur'an sebagai sumber ajaran Islam yang pertama, memiliki peran yang dahsyat pada kehidupan seorang muslim apabila mampu menerjemahkan firman Tuhan pada kehidupan bermasyarakat. Dalam aspek pendidikan khususnya, banyak pelajaran yang bisa diambil sekaligus rujukan yang valid dari ayat-ayat Allah. Terdapat pula pengertian pendidik yang termaktub dalam al-Qur'an.

Pengertian pendidik dalam al-Qur'an ada 4 yang dapat diartikan menjadi pendidik, yaitu 1) Allah SWT, 2) Nabi Muhammad SAW, 3) Orangtua dan 4) guru/pendidik, sebagai berikut $:^{2}$

1. Allah SWT (Sebagai Pendidik Utama)

Allah SWT merupakan Tuhan yang Maha Agung pemilik skenario jagad raya. Para ulama dan pakar bahasa mendiskusikan kata tersebut antara lain apakah ia memiliki akar kata atau tidak. Sekian banyak ulama yang berpendapat bahwa kata "Allah" tidak terambil dari satu akar kata tertentu, tetapi hal itu merupakan nama yang menunjuk kepada zat yang wajib wujud-Nya, yang menguasai seluruh hidup dan kehidupan dan yang kepada-Nya seharusnya seluruh makhluk mengabdi dan bermohon. Tetapi banyak ulama berpendapat bahwa kata "Allah" asalnya adalah "Ilāh", yang dibubuhi huruf alif dan làm dan dengan demikian Allah merupakan nama khusus yang tidak dikenal bentuk jamaknya. Sedangkan Ilāh adalah nama yang bersifat umum dan yang dapat berbentuk jamak (plural) $\bar{A}$ lihah. Dalam bahasa Inggris baik yang bersifat umum maupun khusus, keduanya diterjemahkan dengan tuban, tetapi cara penulisannya dibedakan. Yang bersifat umum ditulis dengan huruf kecil god/ tuhan dan yang bermakna khusus ditulis dengan huruf besar God/ Tuhan. ${ }^{3}$

\footnotetext{
${ }^{1}$ Maragustam, Filsafat Pendidikan Islam Menuju Pembentukan Karakter Menghadapi Arus Global, (Yogyakarta: Kurnia Kalam Semesta, 2016), hal. 203.

2 Sukring, Pendidik dan Peserta Didik dalam Pendidikan Islam, (Yogyakarta: Graha Ilmu, 2013), hal. 77.

${ }^{3}$ Quraish Shihab, Menyingkap Tabir Ilahi, (Jakarta: Lentera, 2005), hal. 4-5.
} 
Menurut Maragustam dalam bukunya yang berjudul Filsafat Pendidikan Islam, dijelaskan bahwa Allah sebagai pendidik utama karena Dia paling tahu tentang hakikat manusia, sebagaimana dalam Q.S Ar-Rahman : 1-4 "Tuban yang Maha pemurah (1) yang telah mengajarkan Al-Qur'an (2) menciptakan manusia (3) mengajarkannya pandai berbicara (4)." Dikutip oleh Maragustam, menurut Maraghi, (1989) ayat ini menerangkan bahwa Allah telah mengajari Nabi Muhammad mengajarkannya pada umatnya. Dia (Allah) telah menciptakan umat manusia ini untuk mengajarinya mengungkapkan apa yang terlintas dalam hatinya dan terpetik dalam sanubarinya. Sekiranya demikian, maka Nabi Muhammad SAW tidak akan dapat mengajarkan AlQur'an pada umatnya. Oleh karena itu manusia sebagai makhluk sosial menurut tabiatnya tak bisa hidup kecuali bermasyarakat dengan sesamanya, maka haruslah ada bahasa yang digunakan untuk saling memaafkan sesamanya dan untuk saling menulis dengan sesamanya yang berada di tempat jauh, disamping untuk memelihara ilmuilmu yang terdahulu, supaya dapat diambil manfaatnya oleh generasi berikutnya dan supaya ilmu itu dapat ditambah oleh generasi mendatang atas hasil usaha yang diperoleh oleh generasi lalu. ${ }^{4}$

Dari berbagai ayat al-Qur'an membicarakan tentang kedudukan Allah sebagai pendidik dapat dipahami dalam firman-firman yang diturunkan kepada Nabi Muhammad SAW, salah satunya: Firman Allah dalam Q.S al-Fātihah/1: 2.

Segala puji bagi Allah, Tuban selurub alam. ${ }^{5}$

Q.S al-Baqarah/2: 31

Dan Dia ajarkan kepada Adam nama-nama (benda) semuanya, kemudian Dia perlibatkan kepada para malaikat, seraya berfirman, "Sebutkan kepada-Ku nama semua (benda) ini, jikea kamu yang benar!’”

Berdasarkan ayat di atas, dapat dipahami bahwa Allah SWT sebagai pendidik bagi manusia. Allah sebagai pendidik mengetahui segala kebutuhan manusia yang dididiknya sebab Dia adalah Sang Pencipta. Perhatian Allah tidak terbatas hanya terhadap manusia saja, tetapi memperhatikan dan mendidik seluruh alam semesta. ${ }^{7}$

\footnotetext{
${ }^{4}$ Maragustam, Filsafat Pendidikan Islam Menuju Pembentukan Karakter Menghadapi Arus Global..., hal. 203-204.

${ }^{5}$ Kementrian Agama RI., Al-Qur'an Al-Jamil, (Bekasi: Cipta Bagus Segara, 2012) ,hal. 2.

${ }^{6}$ Kementrian Agama RI., Al-Qur'an Al-Jamil... ,hal. 2.

${ }^{7}$ Sukring, Pendidik dan Peserta Didik dalam Pendidikan Islam..., hal. 77.
} 
Selain itu, dapat dilihat perbedaan dari aspek proses pengajaran. Allah SWT memberikan bimbingan kepada manusia secara tidak langsung. Allah SWT mendidik manusia melalui wahyu yang disampaikan dengan peraturan malaikat jibril kepada Nabi Muhammad SAW, dan selanjutnya Nabi membimbing umatnya dengan peraturan wahyu. ${ }^{8}$

\section{Nabi Muhammad SAW}

Kedudukan Rasulullah SAW sebagai pendidik ditunjuk langsung oleh Allah SWT. Kedudukan Rasulullah sebagai pendidik ideal dapat dilihat dalam dua hal, yaitu Rasulullah sebagai pendidik pertama dalam pendidikan Islam dan keberhasilan yang dicapai Rasulullah dalam melaksanakan pendidikan. Rasulullah berhasil mendidik manusia menjadi manusia berkualitas baik lahir maupun batin. ${ }^{9}$

Nabi sendiri mengidentifikasikan dirinya sebagai pendidik. Nabi menerima wahyu al-Qur'an yang bertugas menyampaikan petunjuk kepada seluruh umat Islam, kemudian selanjutnya mengajarkan kepada manusia ajaran-ajaran Allah SWT yang tercantum dalam al-Quran tertuang dalam penggalan surat al-A'raf ayat $158 .{ }^{10}$

Katakanlab (Muhammad), "Wahai manusia! Sesunggubnya aku ini utusan Allah bagi kamu semua. ${ }^{11}$

QS. al-An'am ayat 92

Dan ini (al-Qur'an), kitab yang telah Kami turunkan dengan penub berkab: membenarkan kitab-kitab yang (diturunkan) sebelum dan agar engkau memberi peringatan kepada (penduduk) Ummul Qura (Mekah) dan orang-orang yang ada di sekitarnya. Orang-orang yang beriman kepada (kebidupan) akbirat tentu beriman kepadanya (al-Qur'an) dan mereka selalu memelihara shalatnya. ${ }^{12}$

Keberhasilan Rosulullah SAW sebagai pendidik merupakan kombinasi kekuatan antara kemampuan kepribadian, wahyu dan aplikasi ilmu di lapangan. Ilmuilmu yang dimiliki diajarkan kepada para sahabat, sebagai pendidik Rasulullah memiliki kepribadian yang pantas dijadikan al-uswah al-hasanah bagi umat manusia. ${ }^{13}$

\footnotetext{
${ }^{8}$ Sukring, Pendidik dan Peserta Didik dalam Pendidikan Islam..., hal. 78.

${ }^{9}$ Ibid..., hal, 78.

${ }^{10}$ Ibid..., hal, 78 .

${ }^{11}$ Kementrian Agama RI., Al-Qur'an Al-Jamil..., hal. 170.

${ }^{12}$ Kementrian Agama RI., Al-Qur'an Al-Jamil..., hal. 139.

${ }^{13}$ Sukring, Pendidik dan Peserta Didik dalam Pendidikan Islam..., hal. 79.
} 
Saat ini, seribu empat ratus tahun lebih setelah kematiannya, kekuatan risalah dan pengajarannya terus mempengaruhi perjalanan umat manusia seiring perjalanan waktu. Tidak seorang pun yang mampu mempengaruhi pikiran, pemikiran, gagasan dan nasib

3. Orang tua

Setelah anak lahir maka yang pertama kali dikenalnya ialah orangtuanya. Peranan orangtua sangat dominan dalam mendidik anak. Dalam sabda Rosul dikatakan "Setiap anak labir atas dasar fitrah, ibu bapaknyalah yang menjadikan dia Yabudi, Nasrani atau Majusi" (HR. Bukhori Muslim). ${ }^{14}$

Menurut Hassan Langgulung dikutip oleh Sukring, mengatakan bahwa keluarga merupakan institusi pertama dan utama dalam perkembangan seseorang. Bahwa pembentukan kepribadian peserta didik bermula dari lingkungan keluarga. Menurutnya fungsi keluarga adalah menanamkan sifat kasih sayang secara serasi, keluarga juga berfungsi menjaga kesehatan jasmani, kejiwaan, spiritual, akhlak, intelektual, emosional dan sosial. ${ }^{15}$

Pendidik menurut Islam adalah setiap individu yang bertanggungjawab terhadap perkembangan peserta didik. Pendidikan pertama dan utama adalah keluarga. Tugas mendidik sebenarnya berada di pundak orangtua sebab dari merekalah proses kelahiran anak terjadi, orangtua adalah pihak yang paling dekat dengan anak dan paling berkepentingan terhadap anak-anaknya sehingga mereka diberi amanah dan tanggungjawab untuk mengembangkan anak-anaknya. Setiap orangtua memiliki tugas pendidikan. Setiap orangtua memiliki kepentingan terhadap anak-anaknya, yaitu: a) anak sebagai generasi penerus keturunan, b) anak merupakan kebanggan dan belaian kasih orangtua dan c) doa anak merupakan investasi bagi orangtua setelah mereka wafat. ${ }^{16}$ Untuk itu, guru pendidikan agama Islam harus mempunyai karakter humanismultikulturalis yang dicirikan: pertama, tidak terjebak pada pemahaman keagamaan absolut yang rigit, mengingat tafsir agama sangat variatif dan beragam. Kedua, tidak mengedepankan klaim kebenaran (truth claim) dan justifikasi teologis. Ketiga, menunjung tinggi hak asasi manusia dan keadilan, serta

\footnotetext{
${ }^{14}$ Haidar Putra Daulay, Pendidikan Islam dalam Perspektif Filsafat, (Jakarta: Kencana, 2014), hal. 103.

${ }^{15}$ Sukring, Pendidik dan Peserta Didik dalam Pendidikan Islam..., hal. 79.

${ }^{16}$ Ibid..., hal, 79.
} 
memandang keragaman dan perbedaan sebagai sunatullah anugerah Tuhan. Keempat, ikut mempromosikan perdamaian serta aktif mengkampanyekan anti-ujaran kebencian (hate speech) kepada peserta didiknya, baik di media sosial maupun di kehidupan nyata. ${ }^{17}$

Apabila seseorang meninggal, maka putuslah semua amalnya kecuali tiga hal; ilmu yang bermanfaat, amal jariyah yang selalu mengalir dan doa anak sholeh/sholehah untuk orangtuanya. Sebagai calon orangtua khususnya, pendidikan yang pertama yaitu memilih pasangan. Karena, sangat menentukan pola asuh dan pendidikan terhadap anak-anaknya nanti. Seperti pepatah, buah jatuh tak jauh dari pohonnya.

Orangtua adalah orang yang paling berjasa pada setiap anak semenjak awal kelahirannya di muka bumi. Setiap anak melibatkan peran penting orangtuanya, seperti peran pendidikan, peran tersebut menjadi kebutuhan orangtua untuk menemukan eksistensi dirinya sebagai makhluk yang sehat secara aktivitas yang banyak menyebabkan melimpahkan pendidikan anaknya kepada pihak ketiga yaitu guru (pendidik). ${ }^{18}$

Tampak bahwa apa yang disebut dalam al-Qur'an mengenai adanya pendidik menggambarkan adanya perkembangan masyarakat. Misalnya dari sejak zaman Nabi Adam AS, tetapi setelah Nabi maka tugas tersebut diwakilkan kepada orangtua masing-masing. Setelah masyarakat berkembang luas, maka tugas mendidik dibagi lagi kepada orang lain yang secara khusus dipersiapkan untuk menjadi guru/pendidik dalam hal guru/pendidik di sekolah. ${ }^{19}$

\section{Guru/Pendidik}

Dalam kamus besar bahasa Indonesia guru merupakan orang yang kerjanya mengajar; sekolah, gedung tempat belajar. ${ }^{20}$ Dalam konteks pendidikan Islam pendidik sering disebut dengan ustaغ̇, murabbi, mü'allim, mü'addib, mudarris dan mursyid. Seperti dikatakan al-Ghazali yang dikutip oleh Sukring, bahwa pendidik merupakan

17 Miftahur Rohman, "Tinjauan Filosofis Guru Pendidikan Agama Islam HumanisMultikulturalis," Ta'allum: Jurnal Pendidikan Islam 6, no. 1 (2018): 151-174.

${ }^{18}$ Ibid..., hal, 79.

${ }^{19}$ Sukring, Pendidik dan Peserta Didik dalam Pendidikan Islam..., hal. 80.

${ }^{20}$ Suharso dan Ana Retnoningsih, Kamus Besar Bahasa Indonesia, (Semarang: Widya Karya, 2015), hal. 158. 
pelita segala zaman, orang yang hidup semasa dengannya akan memperoleh pancaran cahaya keilmiahannya. Andaikata dunia tidak ada pendidik, niscaya manusia lebih jelek dari binatang, sebab pendidikan adalah upaya mengeluarkan manusia dari sifat kebinatangan (baik binatang buas maupun binatang jinak) didik. Selanjutnya ia mengatakan bahwa dalam Islam orang yang paling bertanggungjawab tersebut adalah orangtua (ayah ibu) anak didik. Tanggung jawab itu disebabkan sekurang-kurangnya oleh dua hal: pertama, karena kodrat, yaitu karena orangtua ditakdirkan bertanggungjawab mendidik anaknya; kedua, karena kepentingan kedua orangtua, yaitu orangtua berkepentingan terhadap kemajuan perkembangan anaknya, sukses anaknya adalah sukses orangtua juga. ${ }^{21}$

Selanjutnya dalam beberapa literatur kependidikan pada umumnya, istilah pendidik sering diwakili oleh istilah guru. Istilah guru sebagaimana dikutip oleh Abuddin Nata menurut Hadari Nawawi guru adalah orang yang mengajar atau memberikan pelajaran di kelas. Secara lebih khusus lagi, ia mengatakan bahwa guru berarti orang yang bekerja dalam bidang pendidikan dan pengajaran yang ikut bertanggungjawab dalam membantu anak-anak mencapai kedewasaan masingmasing. Guru dalam pengertian tersebut menurutnya bukanlah sekedar orang yang berdiri di depan kelas untuk menyampaikan materi pengetahuan tertentu, akan tetapi adalah anggota masyarakat yang harus ikut aktif dan berjiwa bebas serta kreatif dalam mengarahkan perkembangan anak didiknya untuk menjadi anggota masyarakat yang harus ikut aktif dan berjiwa bebas serta kreatif dalam mengarahkan perkembangan anak didiknya untuk menjadi anggota masyarakat sebagai orang dewasa. Dalam pengertian ini terkesan adanya tugas yang demikian berat, yang harus dipikul oleh seorang pendidik khususnya guru. Tugas tersebut, selain memberikan di depan kelas, juga membantu mendewasakan anak didik. ${ }^{22}$

Dari uraian tersebut nampak ketika menjelaskan pengertian guru atau pendidik selalu dikaitkan dengan bidang tugas atau pekerjaan yang harus dilakukannya. Ini

\footnotetext{
${ }^{21}$ Abuddin Nata, Filsafat Pendidikan Islam, (Jakarta: Logos Wacana Ilmu, 1997), hal. 62.

${ }^{22}$ Abuddin Nata, Filsafat Pendidikan Islam..., hal. 63.
} 
menunjukkan bahwa pada akhirnya pendidik itu adalah profesi atau keahlian tertentu yang melekat pada seseorang yang tugasnya berkaitan dengan pendidikan. ${ }^{23}$

Pengertian tersebut jika dilihat pada era global sekarang sedikit berbeda. Karena saat ini kurikulum yang terbaru menggembor-gemborkan pendidikan yang berpusat pada peserta didik (student center), tidak melulu guru yang menjadi pusat (teacher center). Jadi dalam konteks sekarang lebih dominan pada peserta didik, guru sebagai fasilitator pembelajaran. Kalau meminjam istilahnya John Dewey, ia mengartikan pendidikan sebagai upaya pendewasaan.

\section{Hakikat Peserta Didik}

Anak didik merupakan salah satu dari komponen pendidikan yang berpengaruh terhadap pencapaian tujuan pendidikan. Tanpa anak didik, pengajaran tidak akan ada dan pendidikan tidak akan terjadi. Sebagai salah satu komponen pendidikan, anak didik mendapat perhatian yang serius dari para ahli pendidikan. Untuk keberhasilan pencapaian tujuan pengajaran khususnya dan pendidikan pada umumnya anak didik harus diperlakukan sebagai subjek dan objek. ${ }^{24}$

Istilah yang sering digunakan untuk menunjukkan term students (siswa); yaitu tilmidh, (jamak talamidh, talamidha) yang berarti murid dan talib (seeker of knowledge) (jamak talaba, tullab) yang berarti orang yang menuntut ilmu-ilmu (agama) pelajar atau mahasiswa. $^{25}$

Menurut Maragustam, peserta didik dalam pendidikan Islam adalah anggota masyarakat yang berusaha mengembangkan dirinya melalui proses pendidikan menjadi manusia yang mempunyai ilmu, iman-takwa serta berakhlak mulia sehingga mampu menjalankan fungsinya sebagai pengabdi/beribadah kepada Allah dan sebagai khalifah. ${ }^{26}$

Pembahasan berikut ini berusaha menyajikan uraian tentang kehidupan siswa di masa Islam klasik mencakup karakteristik (orang yang paling menonjol) dalam

${ }^{23}$ Abuddin Nata, Filsafat Pendidikan Islam..., hal. 70.

${ }^{24}$ Abuddin Nata, Sejarah Pendidikan Islam Pada Periode Klasik dan Pertengahan..., hal. 129.

${ }^{25}$ Ibid..., hal, 129.

${ }^{26}$ Maragustam, Filsafat Pendidikan Islam Menuju Pembentukan Karakter Menghadapi Arus Global..., hal. 215. 
kehidupan penuntut ilmu itu (murid dan mahasiswa) yakni perihal biaya, waktu dan lama belajar serta pola sosial kehidupan mereka.

\section{Kehidupan Para Siswa di Masa Klasik}

1. Kehidupan Para Siswa di Masa Klasik

a. Karakteristik Murid

1) Pengertian dan Batasan Murid

Murid adalah anak sedang berguru, yang memperoleh pendidikan dasar dari satu lembaga pendidikan. Di awal perkembangan Islam, para penuntun ilmu tidak ada perbedaan. Ketika Rosulullah masih hidup, semua sahabat diberi kesempatan yang sama untuk mendapatkan pengetahuan dan pengalaman tentang ajaran Islam dari Rasulullah SAW. Dalam kenyataannya, tidak semua sahabat dapat memanfaatkan kesempatan untuk menimba dari beliau. Hal ini bisa dipahami karena para sahabat mempunyai pekerjaan dan aktivitas yang beraneka. ${ }^{27}$

Kegiatan pendidikan pada permulaan Islam di rumah Al-Arqom bin Abi Al-Arqam, selanjutnya berpindah ke masjid. Dalam perkembangannya kemudian, kaum Muslim memerlukan tempat khusus untuk kegiatan belajar anak-anak mereka. Mereka menjadikan kuttab sebagai tempat pendidikan dasar. $^{28}$

Di kuttab, para murid mendapatkan pengajaran berupa keterampilan dasar, seperti membaca dan menulis al-Qur'an dan dasar-dasar agama. Dikutip dalam bukunya Abuddin Nata, menurut Hodgson, pendidikan Islam tingkat dasar adalah tempat bagi murid untuk belajar membaca dan menulis. Sementara menurut Stanton dikutip dalam bukunya Abuddin Nata, pada abad pertama Hijriah, pelajaran di sekolah tingkat rendah difokuskan pada pelajaran menulis dan membaca. Kemudian pada abad berikutnya, pelajaran

\footnotetext{
${ }^{27}$ Abuddin Nata, Sejarah Pendidikan Islam Pada Periode Klasik dan Pertengahan..., hal.
} 130.

${ }^{28}$ Abuddin Nata, Sejarah Pendidikan Islam Pada Periode Klasik dan Pertengahan..., hal. 131. 
berkembang dengan diajarkannya ilmu keagamaan, aritmatika, tata bahasa, syair dan sejarah. ${ }^{29}$

Dari gambaran diatas dapat dilihat bahwa perkembangan mata pelajaran yang berikan, sesuai dengan kebutuhan waktu itu. Pada permulaan Islam, belajar membaca dan menulis adalah kebutuhan mendesak. Karena itu, fokus pemberian pelajaran adalah keterampilan membaca dan menulis. Setelah Islam berkembang dan kontak dengan dunia luar semakin intens, pelajaran dasar tidak cukup dengan hanya membaca dan menulis tetapi pelajaran baru pun dimasukkan. ${ }^{30}$

Pada masa klasik tidak ada ketentuan pasti tentang batasan umur bagi seseorang yang mau belajar di kuttab. Para murid yang memasuki lembaga pendidikan dasar ini bervariasi. Ada murid yang mulai memasuki kuttab berumur lima tahun, ada yang berumur tujuh tahun dan bahkan ada yang berumur sepuluh tahun. Bervariasinya umur murid yang memasuki kuttab, tampaknya terkait dengan persiapan mereka. Kesiapan itu bukan saja dari segi fisik dan mental, tetapi juga dari segi ekonomi. ${ }^{31}$

2) Biaya dan Lama Belajar

Biaya selama belajar di kuttab pada dasarnya dibebankan kepada keluarga murid. Orangtua murid membayar dengan sejumlah uang yang dibayar pada setiap minggu atau setiap bulan. Terkadang pembayaran itu dilakukan dengan sejumlah bahan makanan sebagai pengganti uang. Bagi murid yang berasal dari keluarga miskin, diberikan kesempatan belajar secara cuma-cuma. Selain itu, ada pula orangtua yang menitipkan anaknya kepada seornag guru dan untuk biaya selama anaknya belajar, dia memberikan kepada guru tersebut sejumlah harta/biaya. Dalam kasus terakhir ini dialami oleh al-Ghazali dan saudaranya. ${ }^{32}$

Lama belajar di kuttab tergantung pada kemampuan anak didik. Murid yang cerdas dan rajin dapat menyelesaikan belajarnya dalam waktu relatif

${ }^{29}$ Ibid..., hal, 131.

${ }^{30}$ Abuddin Nata, Sejarah Pendidikan Islam Pada Periode Klasik dan Pertengahan..., hal. 132.

${ }^{31}$ Ibid..., hal, 132. 133.

${ }^{32}$ Abuddin Nata, Sejarah Pendidikan Islam Pada Periode Klasik dan Pertengahan..., hal. 
singkat. Sebaliknya, anak yang kurang cerdas dan malas di kuttab kurang lebih lima tahun. Ukuran yang dijadikan dasar untuk kelulusan adalah kemampuan murid menghafal al-Qur'an.

3) Keadaan Murid

Menurut Mahmud Yunus, dikutip dalam bukunya Abuddin Nata, para murid di kuttab belajar enam hari dalam seminggu. Pelajaran dimulai pada hari sabtu dan berakhir pada hari kamis. Waktu belajar dimulai pada pagi hari dan berakhir setelah sholat ashar. Biasanya sehabis sholat dhuhur para murid pulang ke rumah untuk makan. ${ }^{33}$

Dari uraian tersebut dapat dikatakan bahwa para murid pada siang hari lebih banyak bergaul dengan guru dan para murid lainnya di kuttab. Adapun murid yang berada dalam pemeliharaan seorang guru, pergaulannya dengan seorang guru lebih lama dari murid-murid lain yang harus pulang ke rumah setelah pelajaran selesai. Karena itu, dapat diasumsikan bahwa guru yang mengajar di kuttab adalah orang yang terdekat selain orangtua. ${ }^{34}$

Apakah pendidikan dasar di kuttab hanya diikuti oleh murid lelaki saja? Anak-anak perempuan pun memperoleh hak yang sama dengan anak lakilaki dalam belajar, karena menuntut ilmu adalah wajib bagi orang Islam. Walaupun begitu, keikutsertaan perempuan belajar secara terbuka diperselisihkan. Menurut Sjalaby dikutip oleh Abuddin Nata, ia menolak adanya murid perempuan ikut secara langsung belajar dengan murid lelaki di kuttab, meskipun dia mengakui adanya pengajaran untuk perempuan dan anak-anak perempuan. ${ }^{35}$

b. Karakteristik Mahasiswa

1) Pembagian Mahasiswa

Mahasiswa adalah pelajar pada perguruan tinggi. Mereka belajar di perguruan tinggi harus melewati pendidikan dasar dan menengah. Berbeda

${ }^{33}$ Ibid..., hal, 133.

${ }^{34}$ Abuddin Nata, Sejarah Pendidikan Islam Pada Periode Klasik dan Pertengahan..., hal. 134.

\footnotetext{
${ }^{35}$ Ibid..., hal, 134.
} 
dengan sekarang, di masa klasik seorang mahasiswa cukup menyelesaikan pelajaran di lembaga pendidikan dasar. Mahasiswa ditujukan pada mereka yang belajar di halaqah- halaqah dalam masjid atau di madrasah sebagai kalanjutan dari kuttab atau pendidikan dasar. ${ }^{36}$

Pada masa klasik ini, mahasiswa diklarifikasikan ke dalam: (1) tingkat mahasiswa relatif, (2) penerima beasiswa, (3) mahasiswa inti/pilar dan (4) peserta di kelas. ${ }^{37}$

Tingkat mahasiswa relatif terbagi kepada pemula (mubtadi), pertengahan (mutawassit) dan tertinggi (muntahin). Sementara mahasiswa inti/pilar (foundationer) dibagi ke dalam mutafaqqih dan faqih. Mutafaqqih adalah mahasiswa yang berada di tingkat akhir (muntabun) dalam kelas reguler. Sedangkan faqih adalah mahasiswa yang sudah selesai di tingkat akhir dan mendapat persetujuan (licence) untuk mengajar fiqih dan memberi fatwa resmi. ${ }^{38}$

Pembagian mahasiswa oleh Makdisi ini tampaknya dilihat dari berbagai sudut pandang. Ada pembagian mahasiswa dilihat dari berbagai sudut pandang dilihat dari tingkat sebagaimana pembagian pada umumnya. Ada pembagian mahasiswa dilihat dari jumlah beasiswa yang diperoleh dan ada pembagian mahasiswa dilihat dari keaktifan mereka mengikuti perkuliahan. ${ }^{39}$

2) Waktu dan Lama Belajar

Waktu belajar empat hari dalam seminggu. Tiga hari lainnya yaitu selasa, jumat dan sabtu sebagai hari libur. Jadwal kegiatan hari-hari normal di madrasah dan masjid akademi dimulai pada pagi hari dan berakhir pada malam hari. Pagi hari sampai tengah hari diisi oleh mu'id (mahasiswa paling senior) dan mufid (mahasiswa senior yang membantu mahasiswa pemula). Mu'id dan mufid mengulangi materi yang diajarkan syaikh sebelumnya. ${ }^{40}$

${ }^{36}$ Abuddin Nata, Sejarah Pendidikan Islam Pada Periode Klasik dan Pertengahan..., hal. 135.

${ }^{37}$ Ibid..., hal, 135.

${ }^{38}$ Ibid..., hal, 135.

${ }^{39}$ Ibid..., hal, 135.

${ }^{40}$ Abuddin Nata, Sejarah Pendidikan Islam Pada Periode Klasik dan Pertengahan..., hal. 136. 
Lama belajar bagi mahasiswa untuk menyelesaikan bidang hukum, selama empat tahun. Selanjutnya untuk mempelajari bidang studi lain sampai mereka mendapat ijazah mengajar memerlukan waktu yang berbeda bagi setiap mahasiswa. Ibn Wahab (197/813) belajar dengan Malik bin Anas selama 20 tahun. Ali bin Isa Al-Raba'i (410/1019), belajar di bawah asuhan Abu Ali Al-Fahrisi selama 20 tahun. Sharif Abu Ja'far belajar dengan Qadi Abu Ya’la kurang lebih 23 tahun. ${ }^{41}$

Ada juga sebagian mahasiswa yang belajar di bawah asuhan guru besar yang berbeda. Ibn Al-Banna misalnya, dia belajar fiqih di bawah asuhan Abu Tahir bin Al-Ghubari (432/1014), Abu Ali bin Musa (428/1037), Abu AlFadl (410/1019) dan Abu Faraj Al-Tamimi (425/1034). Abd Al-Ghafir AlFarisi belajar dengan pamannya, kemudian belajar dengan Abd Al-Razzaq Al-Mani'i, setelah itu dia belajar dengan imam Al-Haramain Al-Juwaini selama empat tahun. ${ }^{42}$

Dari uraian di atas dapat dipahami bahwa berbedanya alam belajar untuk satu orang mahasiswa terkait dengan mata kuliah yang diambil, dosen (syaikh) yang mengajar dan kemampuan mahasiswa itu sendiri. Dikutip dalam bukunya Abuddin Nata, Hanun Asrohah menyatakan, alasan mengapa batas waktu juga harus ditempuh oleh mahasiswa tidak seragam adalah: ${ }^{43}$

- Karena guru-guru, bahkan lembaga-lembaga pendidikan tidak pernah menawarkan pelajaran khusus yang harus diselesaikan pada waktu tertentu; dan

- Sudah menjadi ciri sistem pendidikan Islam di masa klasik, bahwa pelajar diberi kebebasan untuk belajar kepada siapa saja dan kapan saja ia menyelesaikan pelajarannya. ${ }^{44}$

3) Keadaan Mahasiswa

${ }^{41}$ Ibid..., hal, 136.

${ }^{42}$ Ibid..., hal, 136.

${ }^{43}$ Abuddin Nata, Sejarah Pendidikan Islam Pada Periode Klasik dan Pertengahan..., hal. 137.

${ }^{44}$ Ibid..., hal, 137. 
Tidak terbatasnya waktu yang ditempuh oleh seseorang mahasiswa untuk memperdalam satu bidang studi memberikan kesempatan kepada mahasiswa menjaid orang yang ahli dalam bidangnya. Seorang mahasiswa juga bebas memilih dosen yang disukai dan berganti dengan dosen lain yang diinginkan. $^{45}$

Kebebasan ini memberikan kesempatan kepada mahasiswa memiliki jaringan guru dengan aneka pengalaman yang didapat. Dikutip dalam bukunya Abuddin Nata, menurut Ahmed para mahasiswa membuat daftar para dosen yang pernah mengajarnya. Daftar ini sebagai bukti bahwa dia belajar kepada guru/ulama (dosen) yang terkenal. Tampaknya bagi mahasiswa tertentu belajar dengan beberapa dosen memberikan kebanggaan tersendiri. ${ }^{46}$

Mahasiswa pada masa klasik, terbagi kepada mahasiswa yang belajar di Masjid Jami' secara halaqah dan mahasiswa yang belajar di madrasahmadrasah. Mahasiswa yang belajar di Masjid Jami' ada yang tinggal di rumahrumah dekat masjid dan ada pula yang tinggal di asrama. Mereka pada umumnya belajar secara cuma-cuma. Berbeda dengan mahasiswa yang khusus belajar di rumah dosen tertentu, mahasiswa ini harus membayar sesuai kesepakatan dengan dosen tersebut. Sementara itu, mahasiswa yang belajar di madrasah bisa mengajukan beasiswa dan fasilitas asrama. ${ }^{47}$

Para mahaisiswa yang belajar, mereka duduk mengelilingi seorang syaikh (dosen). Mahasiswa yang memiliki pengetahuan lebih tinggi duduk di depan. Beberapa di antaranya menjadi shubbab (persahabatan), mereka ini memiliki pergaulan yang akrab dengan dosen. Bahkan ada diantara mereka ada yang diangkat menjadi mu'id atau mufid. Mu'id dan mufid ini membantu dosen untuk membimbing para mahasiswa pada sore hari. ${ }^{48}$

\section{A. Tugas dan Peran Pendidik}

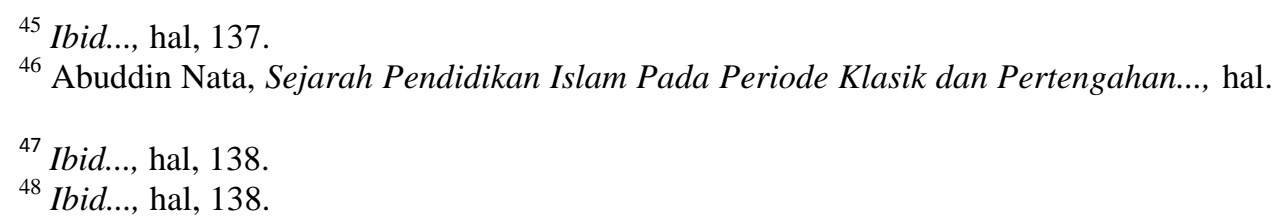

${ }^{46}$ Abuddin Nata, Sejarah Pendidikan Islam Pada Periode Klasik dan Pertengahan..., hal.

${ }^{47}$ Ibid..., hal, 138.

${ }^{48}$ Ibid..., hal, 138. 138. 
1. Masa Klasik

a. Pranata Sosial dan Guru

1) Guru-guru yang mengajar sekolah kanak-kanak (mu'allim al-kuttab)

Para mu'allim al-kuttab (guru sekolah kanak-kanak) mempunyai status sosial yang rendah. Hal ini disebabkan oleh kualitas keilmuan mereka yang dangkal dan kurang berbobot. Mereka dituduh menyebabkan lahirnya kesan yang kurang baik terhadap profesi guru. Di kota Palermo terdapat kurang lebih 300 orang guru sekolah kanak-kanak (mu'allim alkuttab) yang kebanyakan di antara mereka menderita sakit sawan, ceroboh dan bodoh. Namun demikian, tidak semua mu'allim al-kuttab ceroboh dan bodoh. Ada sebagian mereka yang ahli dalam bidang sastra, khat dan fuqaha'. Mereka inilah golongan guru mu'allim al-kuttab yang dihormati dan dihargai seperti al- Hajaja, Al-Kumait, Abdul Hamid AlKatib, Atha' bin Abi Rabah dan lain-lain. ${ }^{49}$

2) Para guru yang mengajar pada putra mahkota (muaddib)

Berbeda dengan mu'allim al-kuttab, para muaddib (pendidik putera mahkota) mempunyai status sosial yang tinggi, bahkan tidak sedikit para ulama yang mendapat kesempatan untuk menjadi muaddib. Hal ini disebabkan karena untuk menjadi muaddib diperlukan beberapa syarat, di antaranya adalah alim, berakhlak mulia dan dikenal masyarakat. Diantara muaddib yang terkenal adalah Al-Dhohhak ibnu Muzahhim Amir AslSya'bi (pendidikan putra-putra Khalifah Abdul Malik ibnu Marwan), AlJa'du ibnu Adham (pendidik Marwan ibnu Muhammad), Yahya ibnu Chalid Al-Barmaki, Al-Kisai (pendidikan Harun al-Rasyid), Al-Ahmar (pendidik Al-Amin), Al-Jazidi (pendidik al-Makmun) dan lain sebagainya. ${ }^{50}$

3) Para guru yang memberikan pelajaran di masjid-masjid dan sekolahsekolah

\footnotetext{
${ }^{49}$ Abuddin Nata, Sejarah Pendidikan Islam Pada Periode Klasik dan Pertengahan..., hal.
} 146.

${ }^{50}$ Abuddin Nata, Sejarah Pendidikan Islam Pada Periode Klasik dan Pertengahan..., hal. 147. 
Guru-guru dari golongan ini telah beruntung mendapat kehormatan dan penghargaan yang tinggi di hadapan masyarakat. Hal ini disebabkan penguasaan mereka terhadap ilmu pengetahuan yang begitu mendalam (rasikh) dan berbobot. Diantara mereka adalah guru ilmu syariat, ilmu bahasa, ilmu pasti dan lain-lain. Banyak para guru yang dibunuh pada masa Khalifah Abdul Malik Ibnu Marwan karena menganut paham Khawarij. Namun ada beberapa guru yang berhaluan khawarij selamat dari pembantaian karena keilmuan yang ia miliki.

Terdapat beberapa guru dari golongan ini yang terkenal di kalangan masyarakat, diantaranya adalah Abul Aswad Al-Duali, Hasan Al-Basri, Abu Wada'ah, Syuarik Al-Qadhi, Muhammad ibnu Al-Hasan, Ahmad ibnu Abi Dawud dan lain sebagainya. ${ }^{51}$

b. Peranan Guru dalam Kehidupan Masyarakat

Keberadaan guru tidak diragukan lagi dalam kehidupan masyarakat mempunyai arti yang penting. Sosok jiwa yang bersih sepi ing pamrib senantiasa menjadi dambaan masyarakat. Guru-guru pada masa klasik selalu dikelilingi oleh para siswa yang datang dari berbagai pelosok wilayah dunia yang bertujuan mendengarkan langsung kajian yang dibawakan oleh gurunya. Karenanya tidak mengherankan apabila sosok individu guru yang alim dan terkenal lebih dominan daripada lembaga pendidikan yang formal. Tokoh-tokoh istimewa tertentu, yang telah mempelajari hadis dan membangun sistem teologi serta hukum yang berlaku di kalangan mereka, senantiasa menarik perhatian murid-murid dari daerah yang jauh dan dekat untuk menuntut ilmu pengetahuan dari

${ }^{51}$ Abuddin Nata, Sejarah Pendidikan Islam Pada Periode Klasik dan Pertengahan..., hal. 148. 
mereka. Maka ciri utama pada masa ini adalah pentingnya peranan individu guru. ${ }^{52}$

Sang guru atau pendidik, setelah memberikan pelajaran kepada muridnya agar menyampaikan ilmunya kepada siapa yang membutuhkannya terutama kaum Muslimin. Baru kemudian tradisi memberikan ijazah sebagai bukti atas selesainya pelajaran yang telah diikuti oleh para murid pada masa Syaikh 'Allamah Agha Buzurk, salah seorang ulama di al-Najaf telah mencurahkan tenaganya guna mengumpulkan, mencatat dan menyusun sejumlah syahadah-syahadah yang pernah dikeluarkan oleh atau untuk ulama-ulama terkenal. Dokumen ijazah yang terkenal paling tua dalam sejarah pendidikan Islam adalah ijazah yang dikeluarkan pada bulan Shafar tahun 304 Hijriah, diberikan oleh Muhammad Ibnu Abdullah Ibnu Ja’far Al-Himyari kepada Abu Amir Said Ibnu 'Amr, karena telah menyelesaikan kitab Qurbul Isnad. $^{53}$

Sudah menjadi tradisi pendidikan Islam pada masa klasik, bahwa guru tidak pernah membatasi kapan murid harus selesai belajar kepadanya, kecuali ia telah menyelesaikan (khatam) kitab yang dikajinya. Murid diberi kebebasan untuk belajar kepada siapa saja dan kapan saja dan bahkan guru tidak pernah menawarkan pelajaran secara khusus yang harus diselesaikan oleh murid pada waktu tertentu. ${ }^{54}$

Walaupun demikian, tidak berarti guru bebas melepaskan muridnya kemanapun ia pergi dan mencari ilmu. Guru tetap mempunyai tanggung jawab atas keberhasilan murid yang pernah belajar kepadanya. Hal ini sebagaimana diungkapkan oleh Al-Jarnuzi dalam kitabnya Ta'lim alMuta'allim bahwa untuk mendapatkan ilmu pengetahuan membutuhkan arahan guru. Karena guru dianggap telah mengetahui bakat yang dimiliki

${ }^{52}$ Ibid..., hal, 148.

${ }^{53}$ Abuddin Nata, Sejarah Pendidikan Islam Pada Periode Klasik dan Pertengahan..., hal. 149.

${ }^{54}$ Ibid..., hal, 149. 
oleh murid, sehingga guru bertanggung jawab atas keberhasilan muridnya. ${ }^{55}$

Kemudian secara sosiologis guru mempunyai tanggung jawab terhadap masyarakat yang berada di sekitar madrasah. Karena keberadaan madrasah akan mempunyai dampak yang positif bagi masyarakat manakala madrasah dapat membantu memainkan peranan dalam pembangunan masyarakat. Selain itu, guru juga mempunyai tanggung jawab dalam memantau perkembangan anak didik yang berada di lingkungan masyarakat sekitar madrasah. Bagaimana pergaulan anak dan peranan apa yang dapat dimainkan anak. Guru mempunyai tugas mengontrolnya sekalipun guru sendiri secara sosiologis punya kewajiban untuk menjadi dinamisator dalam kehidupan masyarakat. ${ }^{56}$

Guru pada masa klasik memegang peranan yang penting dalam proses pendidikan anak, mulai dari menentukan perancanaan sampai melaksanakannya. Oleh sebab itu, tidak mengherankan apabila pada masa ini disebut dengan teacher oriented. Selain itu, guru pada masa ini teratur sudah melaksanakan tugas dan memberikan secara sungguhsungguh dan memperlakukan murid secara adil tanpa ada diskriminasi. ${ }^{57}$

Menurut Hasan Hafidz dikutip dalam bukunya Abuddin Nata, Sejarah Pendidikan Islam menjelaskan secara umum peran guru dapat dibedakan menjadi dua yakni sebagai murabbi dan penggerak masyarakat. Sebagai murabbi dan penggerak masyarakat. Sebagai murabbi ia mempunyai tanggung jawab menjaga kepribadian anak dan mengembangkan segala potensi yang dimilikinya. Sedangkan sebagai penggerak masyarakat, ia mempunyai kewajiban untuk memberikan layanan pada masyarakat dengan baik, membangkitkan dan mengangkatnya ke peradaban yang lebih maju.

Dalam Al-Ghozali, guru sebagai murabbi hendaknya dapat memberikan pendidikan dan pengajaran terhadap anak melalui konsep

${ }^{55}$ Abuddin Nata, Sejarah Pendidikan Islam Pada Periode Klasik dan Pertengahan..., hal. 150.

${ }^{56}$ Ibid..., hal, 150.

${ }^{57}$ Ibid..., hal, 150. 
dan latihan budi pekerti dan dihubungkan dengan lahirnya kebaikan dan kualitas moral. Menurutnya, anak mempunyai hati yang bening dan lembut bagai permata dan lilin yang suatu saat dapat dibentuk dan dikembangkan. Apabila diberi contoh budi pekerti yang baik dan dibiasakan untuk mengerjakannya, niscaya ia akan berkembang secara perlahan dan pasti mengarah kepada kebaikan. ${ }^{58}$

Sedangkan guru sebagai penggerak masyarakat, ia diharapkan tidak membatasi diri sibuk dalam kegiatan kelas yang dibatasi oleh dinding yang memisahkan dirinya dengan kehidupan masyarakat. Namun ia dapat menyatu dengan masyarakat dimana ia hidup dan sambil mengontrol perkembangan anak didiknya dalam kehidupan bermasyarakat. ${ }^{59}$

Para mü'addib, müallim dan ustà் pada masa klasik, mereka mampu memainkan peran dalam kehidupan masyarakat dengan cara bergabung dalam institusi-institusi keilmuan dan perkumpulan-perkumpulan pribadi yang mereka bangun. Mereka melakukan transformasi keilmuan secara ekstensif melalui dialog dan praktik-praktik secara terbuka guna mendidik tenaga profesional dalam bidangnya, seperti Zakaria AL-Razi, yang mendidik sambil melakukan praktik kedokteran dan menangani pasien di rumah sakit. Hal ini ia lakukan untuk melatih tenaga muda yang profesional agar dapat mengabdikan dirinya dalam kehidupan bemasyarakat. ${ }^{60}$

c. Organisasi Guru pada Masa Klasik

Keberadaan guru mempunyai pengaruh yang penting dalam suatu pemerintahan, bahkan kekuasaannya mempunyai andil yang besar dalam kekuasaan khalifah. Hal ini tampaknya tidak terlalu berlebihan, karena guru terhimpun dalam suatu organisasi yang mempunyai power yang dapat mengendalikan kepentingan khalifah, khususnya dalam hal pengangkatan dan pemberian izin untuk menjadi pengajar di suatu

\footnotetext{
${ }^{58}$ Abuddin Nata, Sejarah Pendidikan Islam Pada Periode Klasik dan Pertengahan..., hal.
} 151.

${ }^{59}$ Ibid..., hal, 151.

152.

${ }^{60}$ Abuddin Nata, Sejarah Pendidikan Islam Pada Periode Klasik dan Pertengahan..., hal. 
masjid. Abu Syamah mengatakan "Syarikat gurulah yang berhak untuk menentukan dan memberikan izin kepada seornag guru untuk menjadi pengajar di sebuah masjid walaupun khalifah mempunyai kekuasaan. Namun, dalam hal pemberian izin khelifah meminta pertimbangan dan persetujuan kepada syarikat guru." ${ }^{61}$

Sekalipun organisasi guru pada saat itu belum tertata rapi sedemikain rupa sebagaimana lazimnya sebuah organisasi, tapi keberadaannya mempunyai andil yang besar dalam sebuah pemerintahan dan bahkan organisasi guru dijadikan corong untuk menyebarkan ajaran atau aliran yang dianut oleh penguasa. Hal ini sebagaimana yang terjadi mampu memainkan peran membantu pemerintah dalam menyebarkan aliran atau ajaran yang diyakini oleh penguasa pada saat itu. ${ }^{62}$

2. Jaman Now

Guru adalah kunci kualitas sebuah sekolah. Dalam bukunya Munif Chatib, Sekolahnya Manusia terdapat kutipan pidato Miriam Kronish, Kepala Sekolah SD John Eliot, Needham, Massachusetts yang merupakan sekolah terbaik di Amerika, mengatakan dalam sebuah pidato

"Masa depan pendidikan Amerika ditentukan oleh sebuah kekuatan. Jika saja kami memiliki kekuatan, kekuatan tersebut adalah program utama di sekolah kami, yaitu pelatihan guru. Guru tidak hanya cukup membaca metode-metode pembelajaran terbaru. Guru harus dilatih di dalamnya, seperti halnya aktor atau penyair perlu dilatih. Setelah, guru baru bisa mengajarkan kepada orang lain. Guru profesional adalah gelombang masa depan Amerika. "63

Guru di masa jaman now, diharuskan memiliki ilmu yang nyegoro, maksudnya yaitu memiliki banyak ilmu seluas dan sedalam samudra. Perkembangan zaman, peserta didik sekarang lemah sedikit kebingungan bertanya pada google, sehingga dari sini perlunya terus menggali semangat

${ }^{61}$ Ibid..., hal, 152.

${ }^{62}$ Abuddin Nata, Sejarah Pendidikan Islam Pada Periode Klasik dan Pertengahan..., hal. 152.

${ }^{63}$ Munif Chatib, Sekolahnya Manusia, (Bandung : Kaifa, 2014), hal. 148. 
belajar seumur hidup baik untuk pendidik maupun calon pendidik supaya bisa menumbuhkembangkan potensi, merawat dan melindungi peserta didik.

\section{Kesimpulan}

Dalam istilah bahasa Arab kata pendidik berasal dari tarbiyah diartikan sebagai pendidikan, dan murobbi sebagai pendidik. Asal kata robba , yurobbi, tarbiyatan. Robbun memiliki tiga makna paling tidak yang perlu dipahami; (1) menumbuhkan atau mengembangkan potensi peserta didik (menggali), (2) merawat atau dalam Islam dikenal dengan makna merawat dari yang fitri sehingga tidak menyimpang (merawat sesuatu yang suci sehingga tidak kotor), (3) melindungi peserta didik sehingga terhindar dari sesuatu yang membahayakan. Dalam Islam hakikat pendidik itu ada 4 pengertian yaitu; Allah SWT, Nabi Muhammad SAW, Orangtua dan Pendidik/pengajar.

Peserta didik menurut Maragustam, peserta didik dalam pendidikan Islam adalah anggota masyarakat yang berusaha mengembangkan dirinya melalui proses pendidikan menjadi manusia yang mempunyai ilmu, iman-takwa serta berakhlak mulia sehingga mampu menjalankan fungsinya sebagai pengabdi/beribadah kepada Allah dan sebagai khalifah. Terdapat pendidik dan peserta didik di masa klasik dan masa sekarang (jaman now). 


\section{DAFTAR PUSTAKA}

Kementrian Agama RI., Al-Qur'an Al-Jamil, Bekasi: Cipta Bagus Segara, 2012.

Maragustam, Filsafat Pendidikan Islam Menuju Pembentukan Karakter Menghadapi Arus Global, Yogyakarta: Kurnia Kalam Semesta, 2016.

Nata, Abuddin, Filsafat Pendidikan Islam, Jakarta: Logos Wacana Ilmu, 1997. , Sejarah Pendidikan Islam Pada Periode Klasik dan Pertengahan, Jakarta: Raja Grafindo, 2010.

Putra Daulay, Haidar, Pendidikan Islam dalam Perspektif Filsafat, Jakarta: Kencana, 2014.

Rohman, Miftahur. "Tinjauan Filosofis Guru Pendidikan Agama Islam HumanisMultikulturalis." Ta'allum: Jurnal Pendidikan Islam 6, no. 1 (2018): 151-174.

Shihab, Quraish, Menyingkap Tabir Ilabi, Jakarta: Lentera, 2005.

Suharso dan Ana Retnoningsih, Kamus Besar Bahasa Indonesia, Semarang: Widya Karya, 2015.

Sukring, Pendidik dan Peserta Didik dalam Pendidikan Islam, Yogyakarta: Graha Ilmu, 2013.

Tobroni, Pendidikan Islam Paradigma Teologis, Filosofis dan Spiritualitas, Malang: UMM Press, 2008.

\section{BIODATA}

Nama

Tempat Tanggal Lahir

Jenis Kelamin

Kebangsaan

Agama
: Dini Fauziyati

: Tegal, 10 Oktober 1995

: Perempuan

: Indonesia

: Islam 
Alamat Asal

Email

No.HP
: Ds. Tegalwangi RT 16/RW 05 Talang Kabupaten Tegal.

:dinifauzi233@gmail.com

:089667306577 